\title{
TAKING THE PULSE OF THE EARTH: LITHOSPHERE EVENTS TRACKED BY IN-SITU GEOCHRONOLOGY.
}

\author{
Suzanne Y. O'Reilly ${ }^{1}$ and William L. Griffin ${ }^{1,2}$ \\ ${ }^{1}$ GEMOC ARC National Key Centre, Department of Earth and Planetary Sciences, Macquarie University, Australia; \\ ${ }^{2}$ Exploration and Mining, CSIRO, North Ryde, Australia
}

\section{INTRODUCTION}

The delivery of mantle fragments to the surface by kimberlitic and other seep-seated volcanics has allowed the mapping of compositional domains and architecture of the lithospheric mantle and lower crustal regions, as well as ground-truthing of geophysical datasets and modelling. New techniques for in situ dating of mantle wall-rocks using the Re-Os isotopic system (Pearson et al., 2002) are revealing that these peridotites contain sulfides that record many events in the lithosphere. These range from the original depletion event(s) that likely formed the lithospheric domain to subsequent episodes of fluid addition that accompanied large-scale metasomatic transport, lithosphere reworking and/or younger lithospheric additions. The timing pattern of such events can also be used to test if different cratonic lithosphere domains had common evolution histories or if they docked or separated discretely.

Sulfides with high Os abundance but low ${ }^{187} \mathrm{Os} /{ }^{188} \mathrm{Os}(\gamma \mathrm{Os}$ $<1$ ) and low $\mathrm{Re} / \mathrm{Os}$ and $\mathrm{Pt} / \mathrm{Os}$ ratios commonly are enclosed in primary silicates and if they have ${ }^{187} \mathrm{Re} /{ }^{188} \mathrm{Os}<0.08$ and $\mathrm{Pt} / \mathrm{Os}<0.5$ they are inferred to represent monosulfide solid solution phases that are residual from partial melting or have crystallised from sulfide melts (ie primary; Alard et al., 2000 and Griffin et al., 2002). It is these sulfides that potentially provide information on the timing of lithosphere stabilisation episodes, ie when domains of uppermost mantle were isolated from the convecting mantle by mechanisms such as:

- the partial melting residue from primordial mantle

- cooling of upwelling asthenosphere

- plume accretion to existing lithosphere

- crystallisation from a magma ocean.

\section{SULFIDE RE-OS RESULTS FOR KAAPVAAL TERRANES}

Sulfides with low Os abundance but highly radiogenic Os isotopic values and high $\mathrm{Pt} / \mathrm{Os}$ ratios are inferred to represent trapped sulfide melts (Griffin et al., 2002) which have scavenged radiogenic Os from older lithosphere (Alard et al., 2000, 2002). They record post-stabilisation lithospheric events. They probably were originally interstitial to mantle silicate phases but recrystallisation of mantle peridotites may lead to their subsequent inclusion in the silicates. They record post-stabilisation lithospheric events.

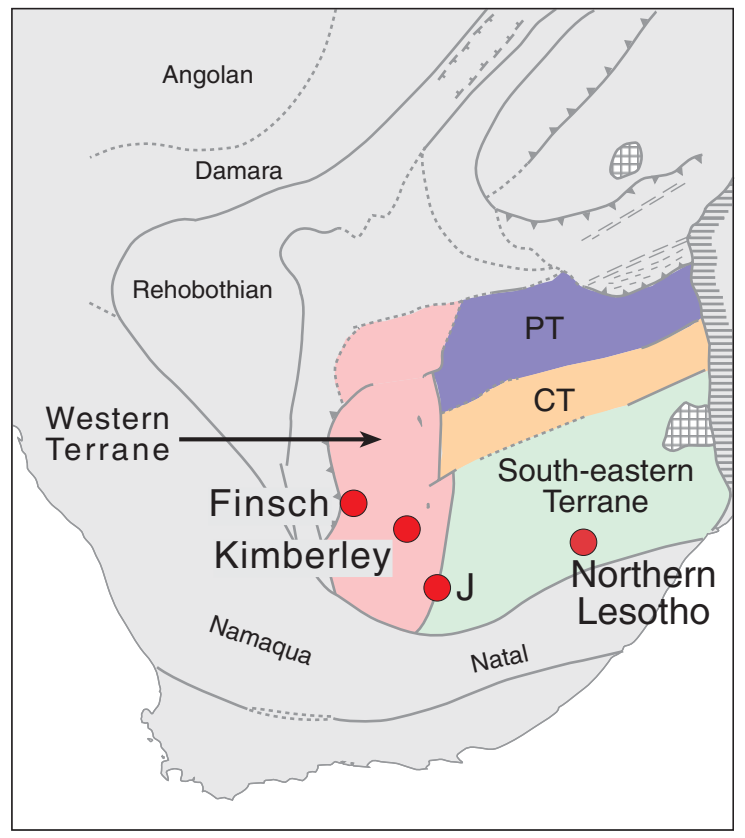

Figure 1. Terrane structure of the Kaapvaal Craton, showing localities sampled in this study; J, Jagersfontein (after Griffin et al., 2003).

The Kaapvaal craton can be divided into terranes based on crustal geological and geophysical data (Fig. 1) and provides a good natural laboratory for the application of this information. Primary sulfides in mantle peridotites from N. Lesotho (the SE Terrane) show a major peak of insitu Re-Os ages from 3.0 to $3.6 \mathrm{Ga}$ corresponding with crustal formation ages in the overlying crust (Fig. 2). There are also broad peaks around 2.2 and $1 \mathrm{Ga}$ and a distinct spike at 2.65-2.75 Ga . Those from the Finsch and Kimberley kimberlites (Western Terrane) show a distinctive age profile with a pronounced peak at $2.8-3.1$ (Fig. 2), again coinciding with the oldest ages in the 
overlying crust, and other clear peaks at 2.5-2.6 Ga and 1.8$2.0 \mathrm{Ga}$.

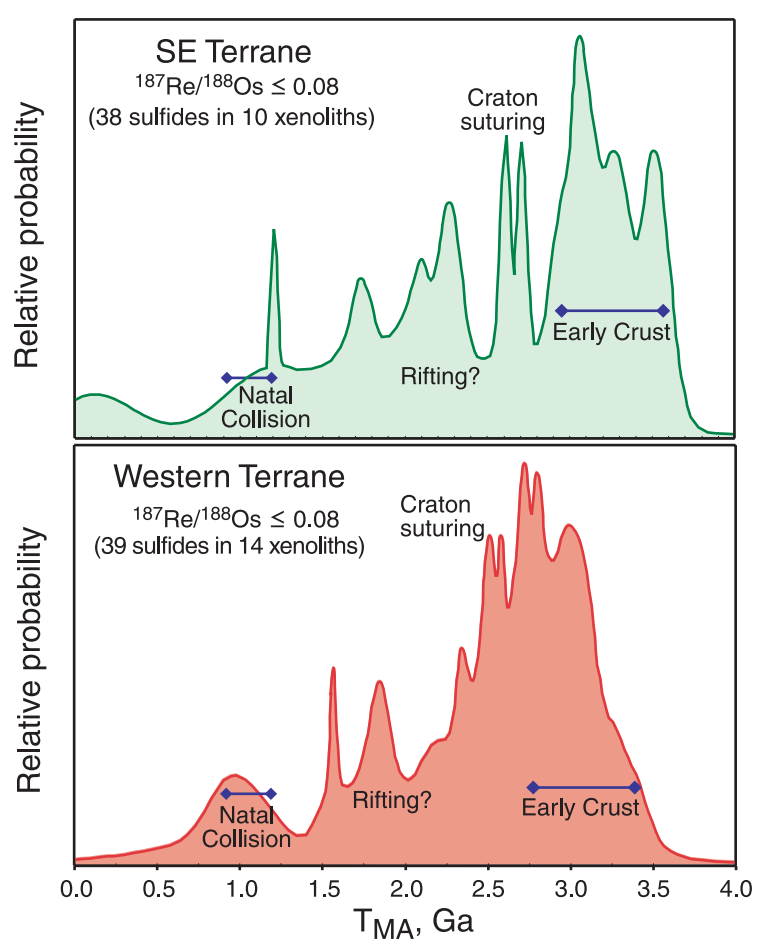

Figure 2. Cumulative-probability plots of the $\mathrm{T}_{\mathrm{MA}}$ model ages of low-Re/Os sulfides from the SE Terrane (N. Lesotho) and the Western Terrane.

Whole-rock Re-Os analyses of our samples give ages lying within the spread of those obtained by in situ analysis, reflecting the presence in the bulk sample of multiple generations of sulfides. The in situ data push back the earliest age of SCLM stabilisation, and indicate the potential for dating individual episodes of SCLM modification on a terrane scale and for identifying mantle terranes with different histories.

\section{IMPLICATIONS FOR MANTLE ARCHITECTURE AND EVOLUTION}

Data obtained so far on mantle rocks from other old terranes (eg Siberia, Slave Craton and exposed sequences in Norway) indicate that significant volumes of lithosphere in cratonic regions were formed by 3b.y. However, it has been demonstrated that very large volumes of juvenile crust were formed at ca $2.7 \mathrm{Ga}$. So far, the in-situ Re-Os data do not suggest that there was a major episode of lithospheric mantle stabilisation directly corresponding to this dominant crustal event. This may be explained by the apparent distribution of kimberlites around the margins of coherent mantle domains identified by geophysical modelling, and overlain by $2.7 \mathrm{Ga}$ crust, resulting in a biased xenolith sampling.

Detailed elastic thickness modelling (using gravity and topographic datasets) in the Slave Craton, Canada (Poudjom Djomani et al., 2003) and in N Siberia (Poudjom Djomani et al., 2001) have shown that kimberlites occur at features identified as gradients in lithosphere strength and tend to outline coherent mantle structures (Fig. 3). This marginal distribution biases the sampling of mantle domains and it may be that the lithospheric mantle beneath the 2.7 b.y. juvenile crustal terranes is rarely penetrated by kimberlites and thus is poorly sampled.

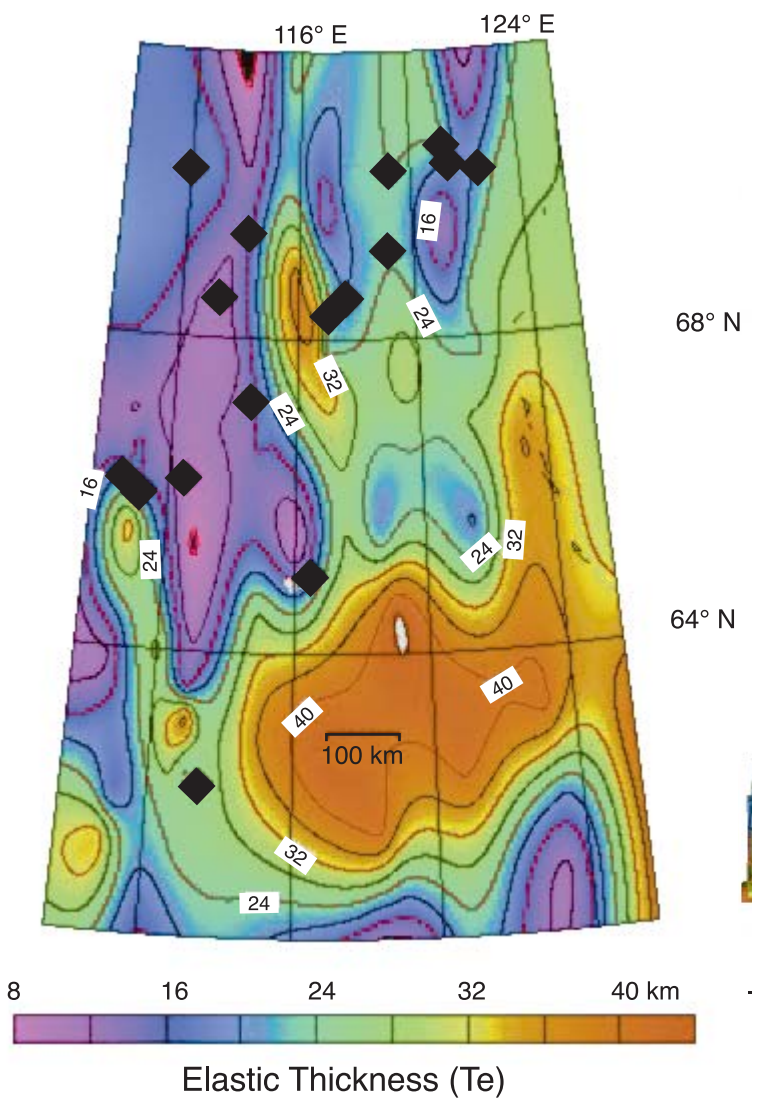

Figure 3. Elastic thickness contours for the eastern Siberian Craton. Kimberlite fields (black diamonds) lie on the flanks of weak zones (Poudjom Djomani et al., 2001).

\section{REFERENCES}

Alard, O., Griffin, W.L., Lorand, J.P., Jackson, S.E. and O'Reilly, S.Y., 2000. Non-chondritic distribution of the highly siderophile elements in mantle sulfides. Nature, 407, 891894.

Alard, O., Griffin, W.L., Pearson, N.J. and O'Reilly, S.Y., 2002. New insights into the Re-Os systematics of subcontinental lithospheric mantle from in-situ analysis of sulfides. Earth Planet. Sci. Lett. 203, 651-663. 
Griffin, W.L., Spetsius, Z.V., Pearson, N.J., and O'Reilly' S.Y. 2002. In-situ Re-Os analysis of sulfide inclusions in kimberlitic olivine: new constraints on depletion events in the Siberian lithospheric mantle. Geochemistry, Geophysics, Geosystems. 2002-11-21.

Griffin, W.L., O'Reilly, S.Y., Abe, N., Aulbach. S., Davies. R. M., Pearson, N.J., Doyle, B.J. and Kivi, K., 2003b. The origin and evolution of Archean lithospheric mantle. Precambrian Research (in press).

Pearson, N.J., Alard, O., Griffin, W.L., Jackson, S.E. and O'Reilly, S.Y., 2002. In situ measurement of Re-Os isotopes in mantle sulfides by Laser Ablation Multi-Collector Inductively-Coupled Mass Spectrometry: analytical methods and preliminary results. Geochim. Cosmochim. Acta, 66, 1037-1050.

Poudjom Djomani, Y., Griffin, W. L., O'Reilly, S. Y., Natapov, L., Erinchek, Y. and Hronsky, J. 2001. Lithospheric boundaries on the eastern Siberian Platform. Preview ASEG, 93, 94-95

Poudjom Djomani, Y., O'Reilly, S. Y., Griffin, W. L. and Doyle, B.J., 2003. Geophysical analysis of the lithosphere beneath the Slave craton (This Abstract Volume).

Contact: Suzanne Y. O'Reilly, GEMOC ARC National Key Centre, Department of Earth and Planetary Sciences, Macquarie University, NSW, 2109, Australia: sue.oreilly@mq.edu.au: www.es.mq.edu.au/GEMOC/ 